\title{
ON THE POPULATION STRUCTURE OF Callinectes danae AND Callinectes ornatus (DECAPODA, PORTUNIDAE), IN GUANABARA BAY, RIO DE JANEIRO STATE, BRAZIL
}

\author{
PATRICIA MARQUES GOLODNE, MARIA CRISTINA OSTROVSKI MATOS \& MARCELO VIANNA \\ Universidade Federal do Rio de Janeiro, Instituto de Biologia, Departamento de Biologia Marinha, Cidade Universitária, Ilha do Fundão, \\ CCS - BI. A, 21949-900, Rio de Janeiro - RJ - Brazil. patriciagolodne@yahoo.com.br
}

\begin{abstract}
Guanabara Bay forms an estuarine ecosystem that is degraded on account of the action of several contamination sources. Despite this, it maintains an important fishery production that is mostly composed by Callinectes danae and Callinectes ornatus swimming crabs. Thirty-three trawlings were conducted from August 2002 to September 2003 in different locations in this bay, as well as visits to the Z-8 fishery colony, and cruises with fishermen. A total of 2,275 specimens were captured, of which 1,445 were $C$. ornatus and $830 \mathrm{C}$. danae. Their largest captures occurred in summer, being $C$. ornatus the most captured species during the season. Continuous reproductive pattern was only verified for $C$. danae. Capture of adult individuals was higher than that of juveniles for both species and sexes. The sex ratios obtained for $C$. ornatus and $C$. danae were significantly different from the expected 1:1. Growth in weight showed a very similar pattern for both species. The fishery recruitment to Guanabara Bay`s trawling fleet started in autumn for $C$. danae ( $35.00 \mathrm{~mm}$ individuals) and in spring for $C$. ornatus (30.00 mm individuals).
\end{abstract}

KEYWORDS: Swimming crabs, reproductive biology, morphometric analyses, fishery recruitment

\section{RESUMO}

Sobre a estrutura populacional de Callinectes danae e Callinectes ornatus (Decapoda, Portunidae), na Baía de Guanabara, Rio de Janeiro, Brasil

A Baía de Guanabara constitui um ecossistema estuarino que se apresenta impactado por diversas fontes de contaminação. Apesar disso, mantém uma importante produção pesqueira composta em sua maioria pelos siris Callinectes danae e Callinectes ornatus. Foram realizados 33 arrastos, de agosto de 2002 a setembro de 2003, em diferentes pontos da baía, idas à colônia de pesca Z-8 e saídas junto a pescadores. Obtiveram-se 2275 exemplares, sendo 1445 C. ornatus e 830 C. danae. As maiores capturas destas espécies ocorreram no verão e $C$. ornatus foi a espécie mais capturada durante a estação. $O$ padrão contínuo de reprodução foi verificado apenas para $C$. danae. A captura de indivíduos adultos foi superior a de juvenis para ambas as espécies e sexos. As proporções sexuais obtidas para $C$. ornatus e $C$. danae foram significativamente diferentes do esperado de 1:1. O crescimento em peso apresentou um padrão similar para ambas as espécies. O recrutamento pesqueiro junto à frota de arrasto da Baía de Guanabara para C. danae iniciou-se no outono, com indivíduos de $35,0 \mathrm{~mm}$, e para C. ornatus na primavera com indivíduos de $30,0 \mathrm{~mm}$.

PALAVRAS-CHAVE: Siris, biologia reprodutiva, análises morfométricas, recrutamento pesqueiro

\section{INTRODUCTION}

Guanabara Bay is an estuarine ecosystem that practically groups the overall metropolitan region of the city of Rio de Janeiro. Despite its undeniable importance, it constitutes one of the most degraded coastal environments in the country (Amador 1997). Nonetheless, even receiving the pouring out from domestic and industrial sewages and from the noncontrolled placing of solid residues, the bay is able to maintaining an important fishery production (Jablonski et al. 2006).

In Guanabara Bay, crustacean fishery has a prominence place and specially targets the pinkshrimps (Farfantepenaeus brasiliensis (Latreille, 1817) and Farfantepenaeus paulensis (PérezFarfante, 1967)). Additionally, the species belonging to the Callinectes genus also present high exploitation potential, especially the blue-crabs Callinectes danae Smith, 1869 and Callinectes ornatus Ordway, 1863. Inside the bay, these species are caught by liftnet and otter trawl. However, trawl fishery does not target these species that are captured as pink-shrimp fishery bycatch (Jablonski et al. 2006).

Despite their high fishery potential in Guanabara Bay, there are only a few investigations on the biology of these species in this ecosystem, such as the studies by Lavrado et al. (2000), Carvalho-Cunha (2003), Keunecke (2006) and Keunecke et al. (2008a, b).Therefore, the aim of this study was to produce information on the population structure of the swimming crabs $\mathrm{C}$. danae and C. ornatus, aiming to improve the knowledge on their biology in Guanabara Bay.

\section{MATERIALS AND METHODS}

Guanabara Bay is characterized as a region of mixture of the saltiest waters in the Atlantic Ocean with the less salty waters from the 35 rivers of the drainage basin (Kjerve et al. 1997). The bay has a channel in its median portion which guarantees its self-depuration potential through the renewal of its waters due to the circulation induced by tidal currents (Villac et al. 1991). The regional climate is tropical humid wet with two well- 
defined seasons: wet warm summers from December to April and dry cool winters from July to August. Horizontal salinity variation decreases from the bay entrance towards the most inner areas, unlike the horizontal temperature variation (Kjerve et al. 1997).

Biological samples were obtained by 33 trawlings during the period from August 2002 to
September 2003, in different areas of Guanabara Bay. The region comprised by this study was the northeast of Rio-Niterói Bridge up to the surroundings of Ilha do Governador (Figure 1). These trawlings were carried out for commercial purposes and only fishery samples were collected.

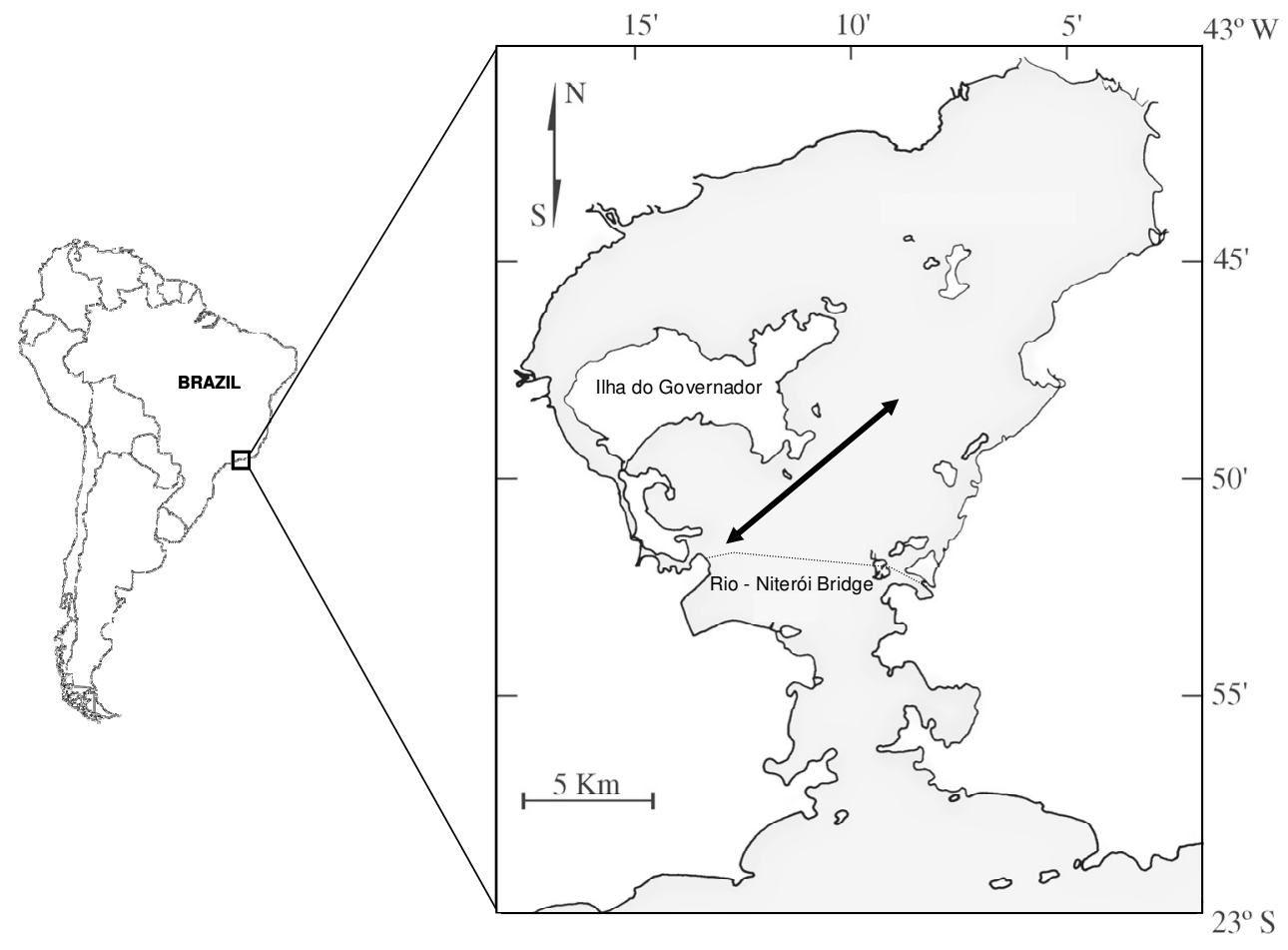

Figure 1. Map of Guanabara Bay showing the range area of the collecting sites.

The ship used was considered a standard commercial shrimp trawler. The total length of the boat was $9.5 \mathrm{~m}$ with $36 \mathrm{hp}$ motor potency and a mesh size of $18 \mathrm{~mm}$ at the codend. Trawlings were carried out at dawn with a duration of approximately one hour. Visits to the Z-8 fishery colony (comprehending landing areas in Niterói - RJ and São Gonçalo - RJ) were performed, as well as cruises with the fishermen to obtain empirical data on swimming crab fishery. This survey was performed due to the scarcity of works which contemplate fishery, particularly that of swimming crabs in the bay.

Species were identified according to Williams (1974). As proposed by Williams (1974), sexual maturation of the individuals was determined through format and adherence of abdomen to thoracic sternites. Total weight (Twt-g), carapace width (including lateral spines) (Cw-mm), and total length (carapace length without the epistomial spine measurement) (TI-mm) were measured in each individual.

The relationships between total length and carapace width and total weight and carapace width were obtained separately, for both sexes. Carapace width data were grouped in 21 classes of $5.0 \mathrm{~mm}$ of amplitude, and were later represented by histograms. Fishery recruitment, that is, initial size and time in which the individuals were available for capture, was assessed by the graphic analysis of frequency distribution of carapace widths. For verifying the existence of statistically significant differences in sex ratio, chi-square test was applied according to Zar (1996). The test used the absolute frequency for total period of sampling and seasonal absolute frequencies, for males and females. 


\section{RESULTS}

A total of 2,275 specimens were collected, being 1,445 Callinectes ornatus (63.5\%) and 830 Callinectes danae (36.5\%). Seasonal distribution showed that $C$. danae as well as $C$. ornatus were captured along the year. For both species and sexes, the highest values of capture occurred during summer. However, males of C. danae occurred in spring as well. Ovigerous females of C. danae were observed all year round, which did not hold true for $C$. ornatus, since no ovigerous females were recorded in autumn. (Table 1). Regarding sexual maturity, a predominance of adult individuals was recorded for both species and sexes (Figure 2).

Table 1. Seasonal occurrence of Callinectes danae and Callinectes ornatus, females, ovigerous females and males. The number between brackets represents the number of ovigerous females within the total amount of females.

\begin{tabular}{c|ccc|ccc}
\cline { 2 - 7 } \multicolumn{2}{c|}{ Callinectes danae } & \multicolumn{3}{c}{ Callinectes ornatus } \\
\hline $\begin{array}{c}\text { Seasons of } \\
\text { the year }\end{array}$ & females & males & total & females & males & total \\
\hline Spring & $52(12)$ & 45 & 97 & $20(11)$ & 35 & 55 \\
Summer & $246(70)$ & 42 & 288 & $123(23)$ & 831 & 954 \\
Autumn & $159(41)$ & 31 & 190 & $104(0)$ & 142 & 246 \\
Winter & $229(32)$ & 26 & 255 & $119(22)$ & 71 & 190 \\
\hline Total & $\mathbf{6 8 6 ( 1 5 5 )}$ & $\mathbf{1 4 4}$ & $\mathbf{8 3 0}$ & $\mathbf{3 6 6 ( 5 6 )}$ & $\mathbf{1 0 7 9}$ & $\mathbf{1 , 4 4 5}$ \\
\% & $\mathbf{8 2 . 7 ( 2 2 . 6 )}$ & $\mathbf{1 7 . 3}$ & $\mathbf{1 0 0}$ & $\mathbf{2 5 . 3 ( 1 5 . 3 )}$ & $\mathbf{7 4 . 7}$ & $\mathbf{1 0 0}$ \\
\hline
\end{tabular}

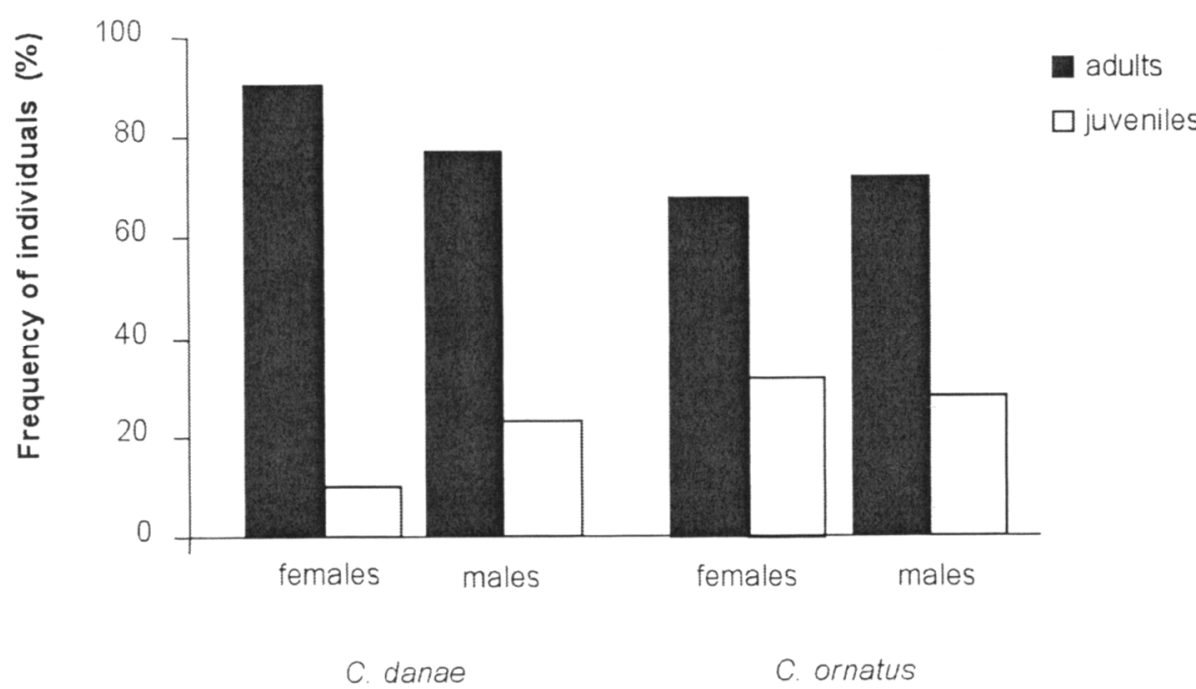

Figure 2. Percentage of adults and juveniles of Callinectes danae and Callinectes ornatus females and males.

The sex ratio found for $C$. danae (1.0M:4.8F) was significantly different from the expected ratio $\left(x_{2}=353.9 ; \mathrm{p}<0.01\right)$. For $C$. ornatus $(3.0 \mathrm{M}: 1.0 \mathrm{~F})$, the same pattern occurred $(x 2=351.8 ; p<0.01)$.

The relationship between total length $(\mathrm{TI})$ and carapace width $(\mathrm{Cw})$ for $C$. danae can be expressed by the equations $\mathrm{TI}=0.4192 \mathrm{CW}+1.8408$ (females) and $\mathrm{TI}=0.4644 \mathrm{Cw}+1.7575$ (males), both presenting high values of the determination coefficient $\left(R^{2}\right), 0.88$ and 0.92 , respectively (Figure 3). 


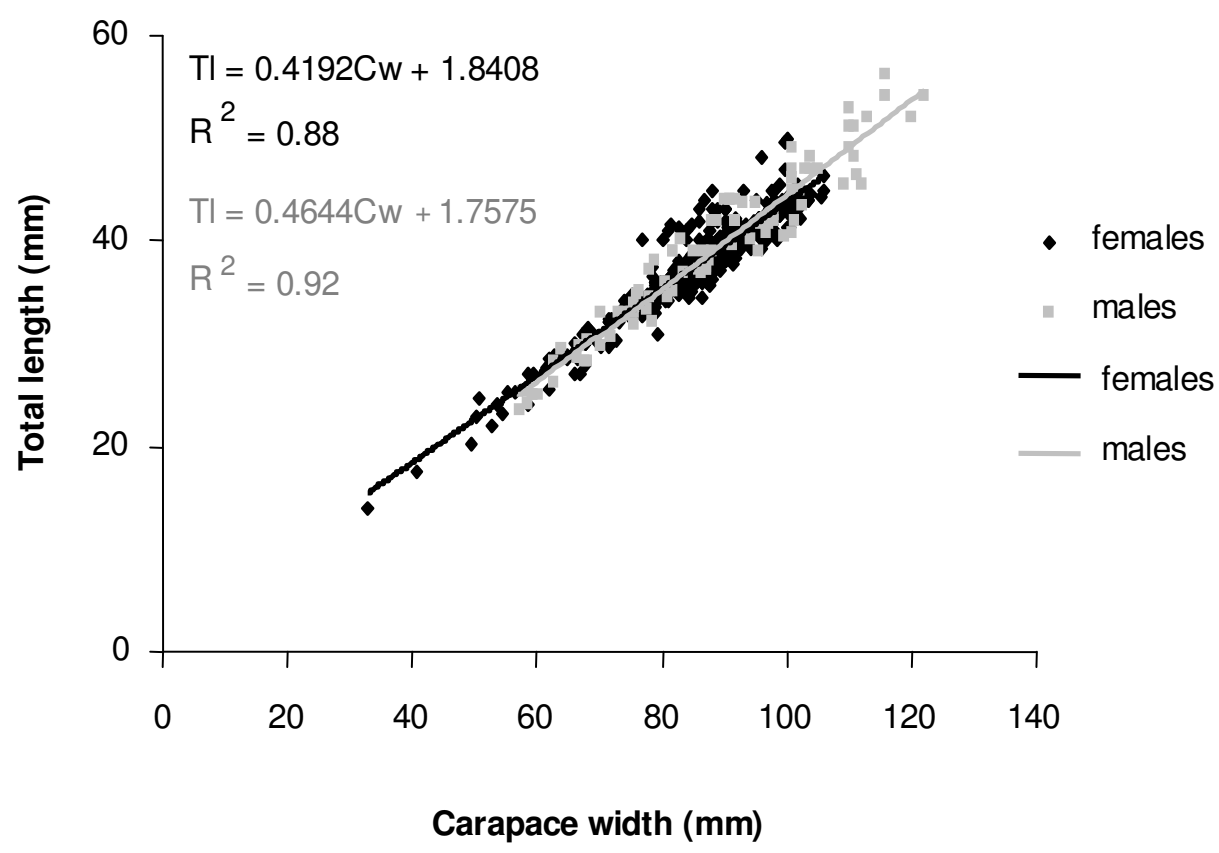

Figure 3. Morphometric relationship between total length (TI) and carapace width $(\mathrm{Cw})$ for female and male specimens of Callinectes danae.

For $C$. ornatus, the relationship $\mathrm{TI} \times \mathrm{Cw}$ can be expressed by the equations: $\mathrm{TI}=0.4251 \mathrm{CW}+1.0689$ equations present high values of the determination (females) and $\mathrm{TI}=0.4663 \mathrm{Cw}+1.4420$ (males). Both coefficient, 0.98 and 0.96 , respectively (Figure 4).

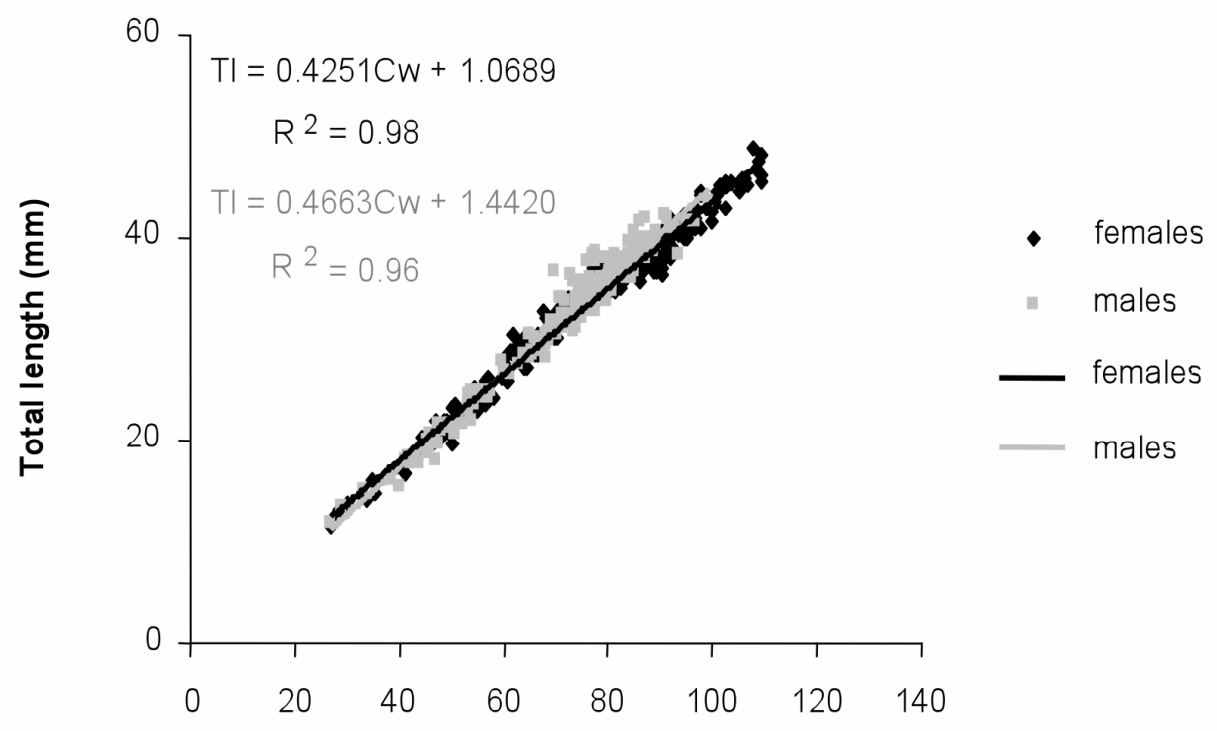

Carapace width $(\mathrm{mm})$

Figure 4. Morphometric relationship between total length (TI) and carapace width $(\mathrm{Cw})$ for female and male specimens of Callinectes ornatus.

The relationship, for $C$. danae, between total weight (Twt) and carapace width $(\mathrm{Cw})$ was expressed by the equations $\mathrm{Twt}=0.6 .10^{-4} \mathrm{Cw}^{2.9937}$ (females) and Twt $=1.10^{-4} \mathrm{Cw}^{2.8706}$ (males). Both relationships presented high values of the determination coefficient $\left(R^{2}\right), 0.92$ and 0.95 , respectively (Figure 5). 


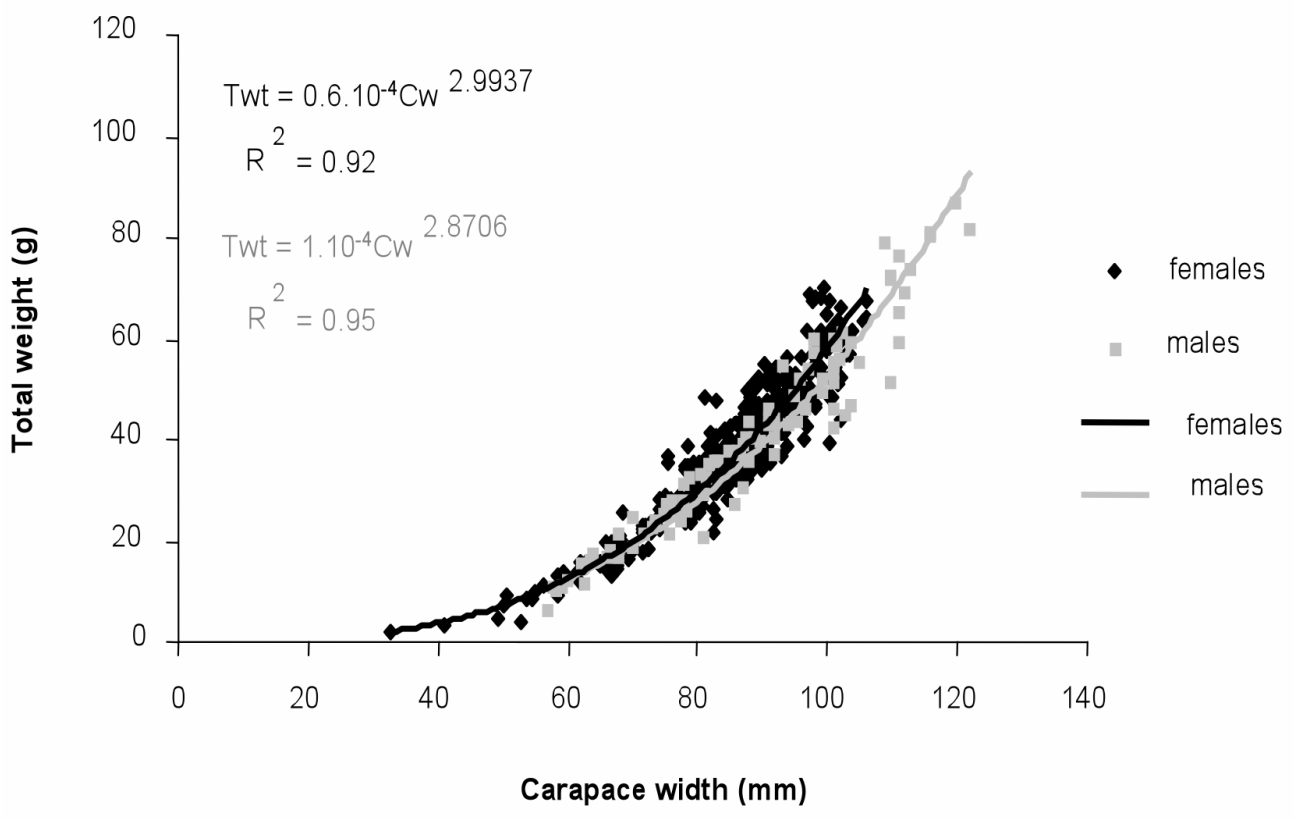

Figure 5. Morphometric relationship between total weight (Twt) and carapace width $(\mathrm{Cw})$ for female and male specimens of Callinectes danae.

For $C$. ornatus, the estimated relationship Twt $x$ (males), with high values of the determination $\mathrm{Cw}$ was expressed by the equations Twt $=4.10^{-5}$ coefficient, 0.98 and 0.95 , respectively (Figure 6). $\mathrm{Cw}^{3.1041}$ (females) and Twt $=3.10^{-5} \mathrm{Cw}^{3.1561}$

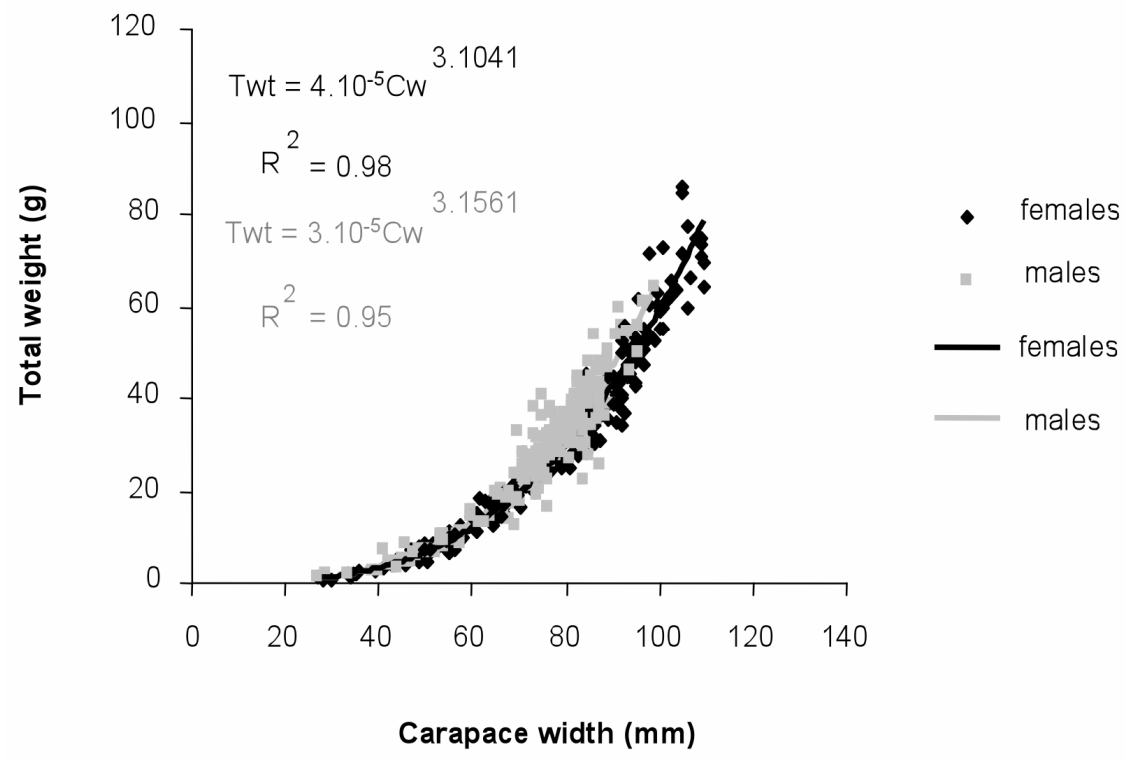

Figure 6. Morphometric relationship between total weight (Twt) and carapace width $(\mathrm{Cw})$ for female and male specimens of Callinectes ornatus.

By superposing the curves of $C$. danae and $C$. ornatus males and females, it was observed that there was a partial overlap among females, being $C$. ornatus females a little wider and heavier. Among males, the overlap was not so marked, being $C$. ornatus males proportionally heavier, although less wide than $C$. danae specimens (Figure 7). 


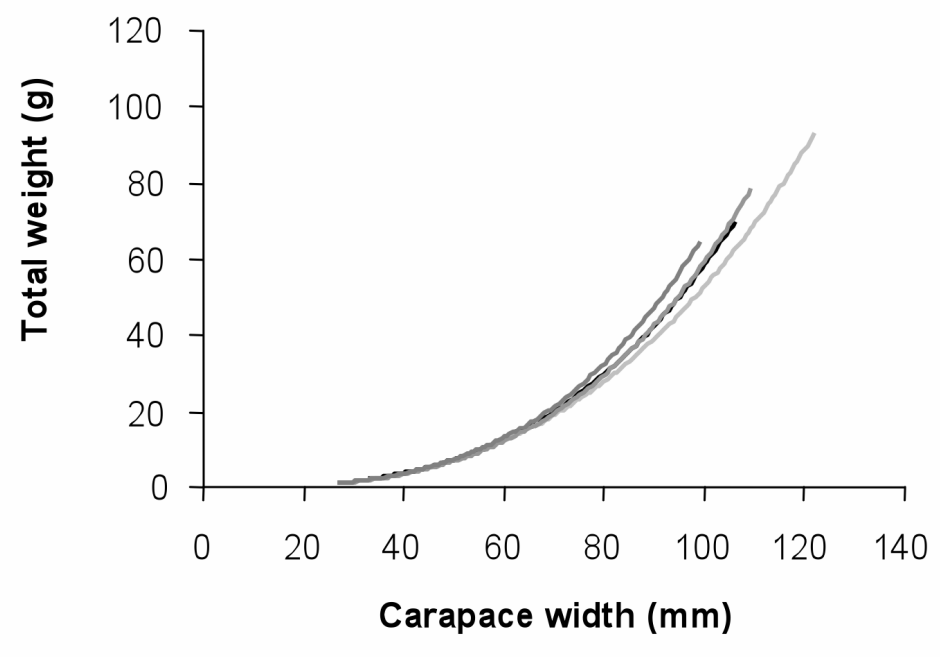
- C. danae females
C. danae males
- C. ornatus females
C. ornatus males

Figure 7. Comparison of the curves of the relationship between total weight (Twt) and carapace width (Cw) for female and male specimens of Callinectes danae and Callinectes ornatus.

Frequency distribution of carapace width modal value of $90.00 \mathrm{~mm}$. For males, variation was evidenced the capture of $C$. danae females with from 40.14 to $122.00 \mathrm{~mm}$ with two modal peaks; the amplitude between 32.85 and $116.20 \mathrm{~mm}$ with a first in 80.00 , and the second in $105.00 \mathrm{~mm}$ (Figure 8).

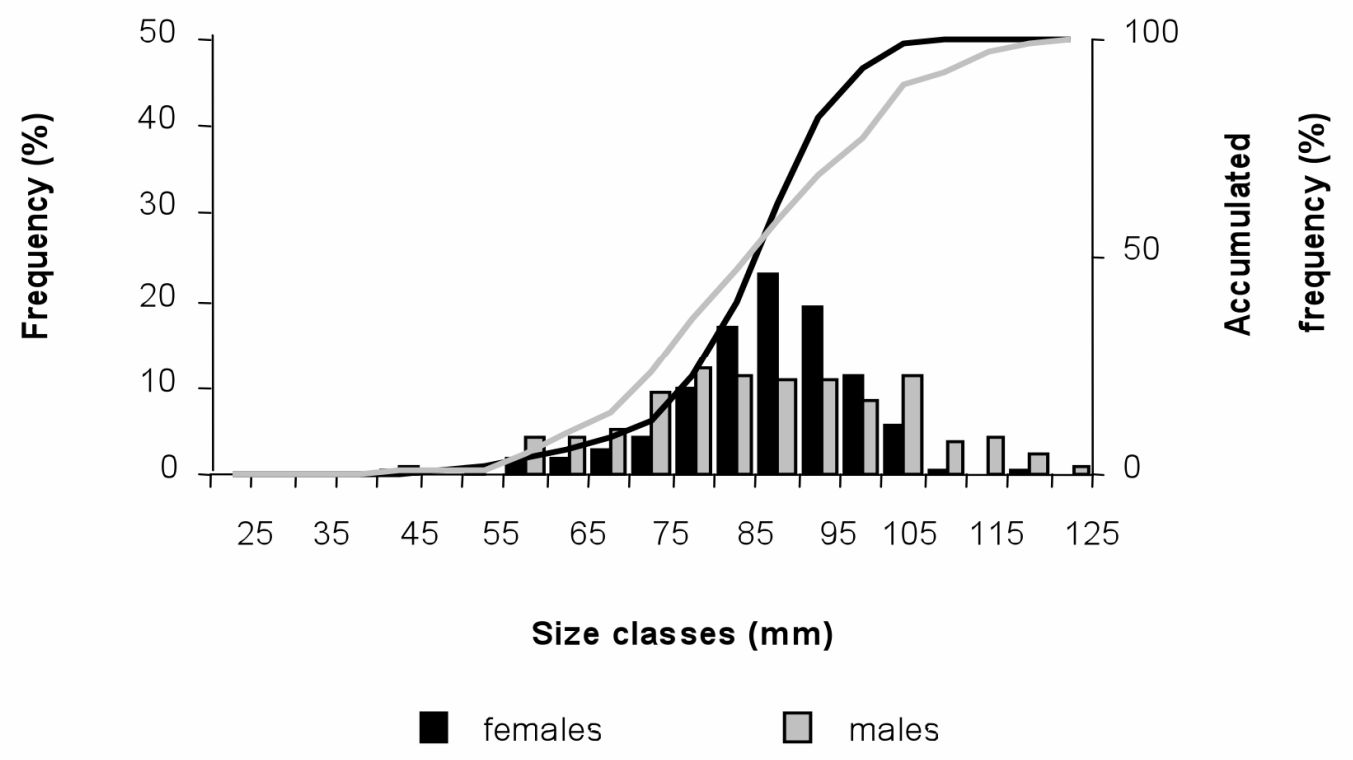

Figure 8. Relative frequency of carapace size for female and male specimens of Callinectes danae.

Carapace width, for $C$. ornatus females, ranged from 26.74 to $109.30 \mathrm{~mm}$ with two modal peaks; in $65.00 \mathrm{~mm}$ and $95.00 \mathrm{~mm}$. For males, it ranged from
26.96 to $99.13 \mathrm{~mm}$ with the occurrence of two modal peaks; the first in 85.00 , and the second in $65.00 \mathrm{~mm}$ (Figure 9). 


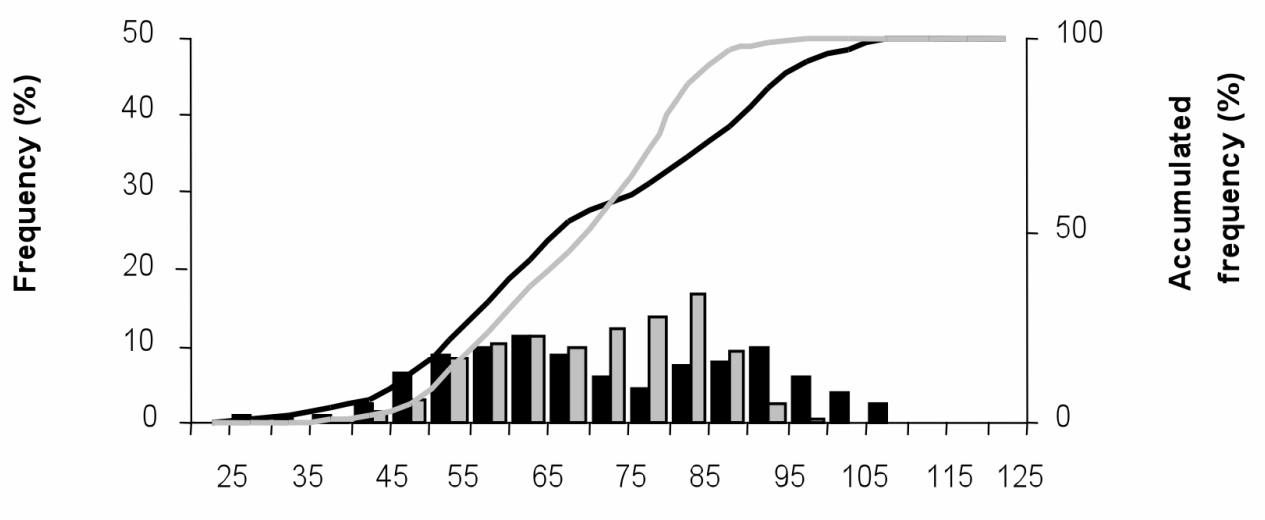

Size classes $(\mathrm{mm})$

females

males

Figure 9. Relative frequency of carapace size for female and male specimens of Callinectes ornatus.

Fishery recruitment observed for $C$. danae started in spring with individuals over $30.00 \mathrm{~mm}$ started in autumn with individuals larger than 35.00 (Figures 10 and 11).

$\mathrm{mm}$. The recruitment observed for $C$. ornatus fishery
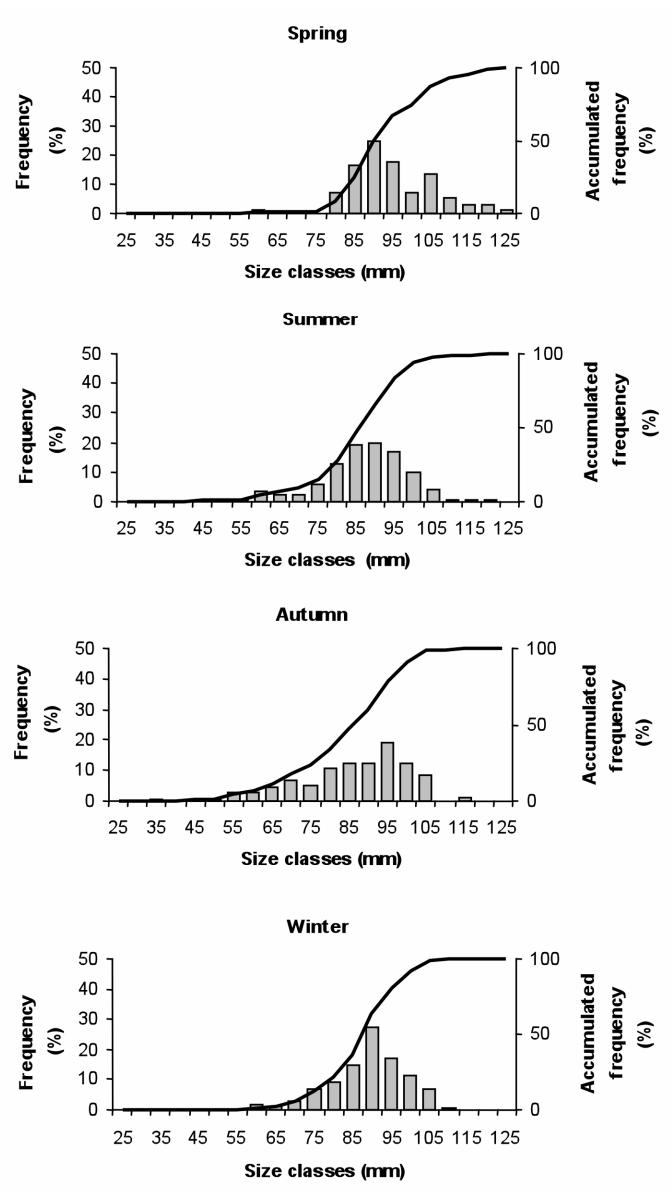

Figure 10. Seasonal relative frequency of carapace size for female and male specimens of Callinectes danae. 

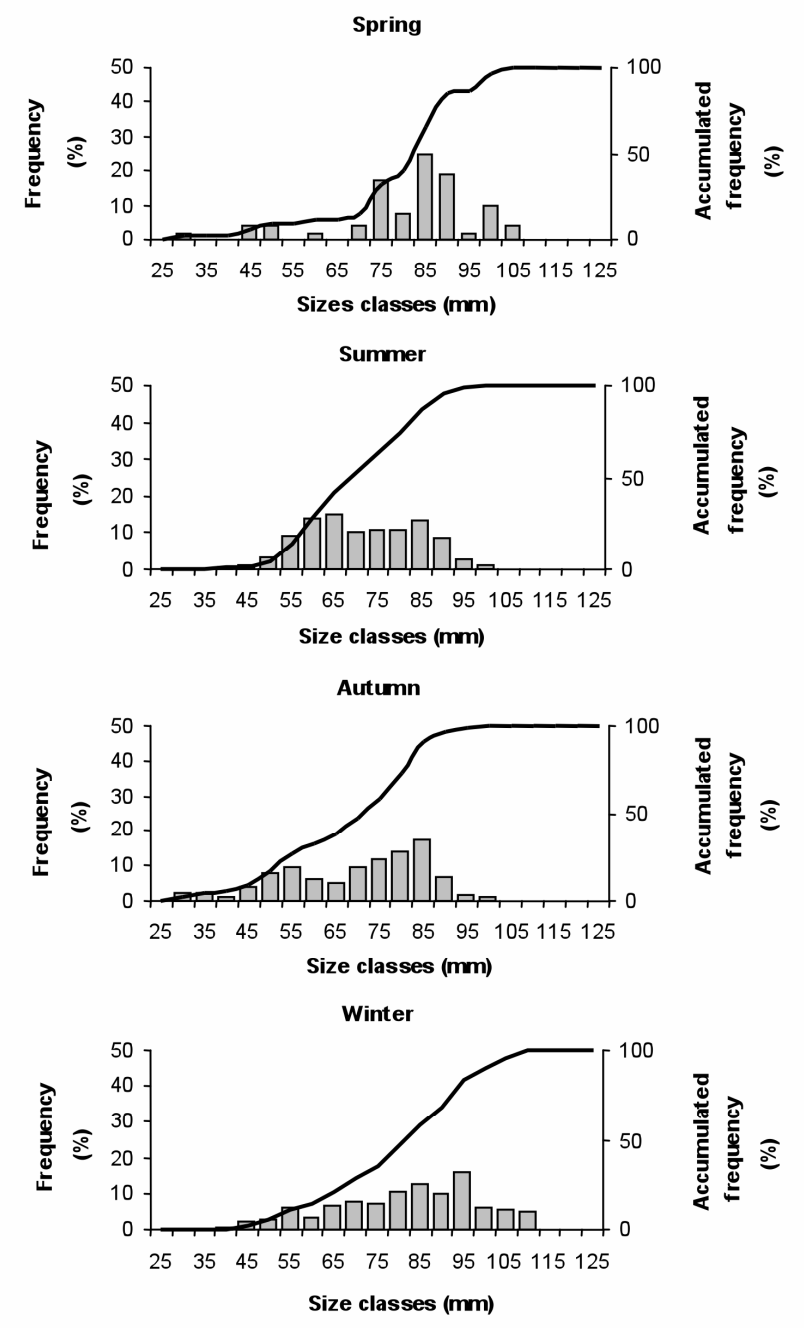

Figure 11. Seasonal relative frequency of carapace size for female and male specimens of Callinectes ornatus.

In the swimming crab fishery in Guanabara Bay, the largest capture, as described by the community, occurs in the end of spring, and it extends through the middle of summer in two fishing modalities: (1) trawling, following the largest period of shrimp fishery which occurs in the regions closer to the central channel, and (2) liftnet which occurs in the inner areas next to mangroves. During the pinkshrimp closed season (from March to May), fishermen change the fishing methods from liftnets to trawling, resulting in a decrease in the incidental catch of swimming crabs. However, during the crab (Ucides cordatus, Linnaeus, 1763) closed season (from October to December), part of these collectors targets the swimming crabs, a fact which would explain the increase in liftnet fishery during the period of the largest capture of these species.

\section{DISCUSSION}

In past studies on the spatial distribution of Callinectes danae and Callinectes ornatus in Ubatuba, it was verified habitat partition between these two species (Negreiros-Fransozo \& Fransozo 1995). In our study, as well as in that of Lavrado et al. (2000) and Carvalho-Cunha (2003), which were also carried out in Guanabara Bay, this pattern was not observed, since both species were captured in the study area.

In agreement with the present study, the highest abundance of $C$. ornatus was also observed by Negreiros-Fransozo \& Fransozo (1995), Pinheiro et al. (1997), Reigada \& Negreiros-Fransozo (2001) in Ubatuba (SP) and by Lavrado et al. (2000) and Carvalho-Cunha (2003) in Guanabara Bay. According to Pinheiro et al. (1997) in their work in Ubatuba, C. omatus presented a wide ecological niche which overlapped that 
of other species of portunids, thus being considered a generalist species. Taking this into consideration, we assume that $C$. omatus, in Guanabara Bay, shows the same behavior described above.

The largest captures of $C$. ornatus and $C$. danae for both sexes followed a seasonal variation, with the highest values occurring in summer, whereas for $C$. danae males, a similar pattern was observed in spring. It is during this period of the year, in Guanabara Bay, that the fishing effort targeting shrimp increases (Jablonski et al. 2006). The swimming crabs, captured as bycatch of shrimp fishery, follow this same trend. It is worth to notice that 22 trawlings, out of a total of 33 , were done during summer.

In tropical and subtropical regions it is known that swimming crab reproduction is a continuous process since environmental conditions are permanently favorable for feeding, gonadal development, and larval hatching (Costa \& NegreirosFransozo 1998 and Negreiros-Fransozo et al. 1999). In the present study, a continuous reproductive pattern was observed for C. danae, which is in agreement with investigations performed in similar habitats (e.g. Ubatuba $\left(23^{\circ} \mathrm{S}, 45^{\circ} \mathrm{W}\right)$ ) (Costa \& Negreiros-Fransozo,1998; Chacur et al., 2000; Chacur \& Negreiros-Fransozo, 2001). However, for C. ornatus, this pattern was not observed since (1) no ovigerous female was captured during autumn and (2) no juvenile individual was continuously captured along the period of this study. Hence, in Guanabara Bay, the absence of this pattern may indicate that ovigerous females were not captured because they occupy areas not covered by the trawlings, as observed in the work by Carvalho-Cunha (2003) who reported that the presence of ovigerous females was only verified at the bay mouth. Besides, Keunecke (2006) in Guanabara Bay observed that both species presented a continuous reproductive pattern.

The capture of adult individuals, in our study, was higher than that of juveniles, both for $C$. danae and $C$. ornatus, in both sexes. This result may be related to the different site occupation, according to size or age. Partition of habitats was already verified by Buchanan \& Stoner (1988) in Porto Rico and in Brazil by Negreiros-Fransozo \& Fransozo (1995), Negreiros-Fransozo et al. (1999) and Chacur \& Negreiros-Fransozo (2001) in Ubatuba (SP), and by
Severino-Rodrigues et al. (2001) in Santos and São Vicente (SP). According to Buchanan \& Stoner (1988), adult swimming crabs may choose most desirable areas in terms of physical parameters and food supply, while juvenile individuals will better survive in sites where there are fewer predators and more protection, namely shallower areas and mangroves.

The sex ratio obtained for $C$. ornatus differed from the expected, revealing the male dominance in the studied area. This result was also verified by Mantelatto \& Fransozo (1996) and NegreirosFransozo et al. (1999) in studies performed in Ubatuba and by Carvalho-Cunha (2003) and Keunecke (2006) in Guanabara Bay. A hypothesis for the explanation of this pattern may be the fact that a single female may copulate with many males during the same reproductive period (Negreiros-Fransozo et al. 1999) and adult females may shift to off-coast areas where temperature and/or salinity conditions may be favorable to spawning (Negreiros-Fransozo \& Fransozo 1995). Another possible hypothesis is the spatial stratification between sexes, with males preferentially occupying environments more easily sampled by trawl net, as this was the instrument used in the capture of the specimens in all the studies cited. The stratified behavior regarding sex and individual size for C. ornatus was verified by Pita et al. (1985) in a study in the Bay-Estuary complex of Santos (SP).

Concerning $C$. danae, an evident dominance of females was observed.

This result was also verified by Branco \& Thives (1991) in Itacorubi Mangrove (SC) and by CarvalhoCunha (2003) and Keunecke (2006) in Guanabara Bay. As stated by Branco \& Thives, (1991) that pattern may indicate the migration of ovigerous females to areas of a higher salinity for spawning and male permanence in waters of low salinity, which are areas of growth and copulation, as rivers and mangroves. In a study performed by SeverinoRodrigues et al. (2001) in rivers of the estuarine region of Santos and São Vicente, a higher proportion of males over females was found (2.0M:1.0F). This result reinforces the idea of male permanence in low salinity waters. In Guanabara Bay, this same pattern seems to be occurring between males and females.

The equations obtained through the relationship 
between total weight and carapace width showed a very similar pattern for both sexes and species, but particularly among females. This similarity indicates that both species do not show sexual dimorphism related to weight, as suggested for Arenaeus cribarius (Lamarck, 1818) in a study in Ubatuba (Pinheiro \& Fransozo 1993). Similarity in shape of both species is highly supported by phylogenetic studies where it is stated that they are the closest among the Callinectes genus (Weber et. al. 2003).

Frequency distribution of carapace width for both species and sexes revealed that Guanabara Bay is occupied by different population strata. As observed by Keunecke (2006), C. ornatus and C. danae presented a continuous reproductive pattern. Taking this into account, it was possible to infer that the populations of $C$. ornatus and $C$. danae in Guanabara Bay were represented by many cohorts, as it was demonstrated in our results.

The fishery recruitment observed for $C$. danae started in the beginning of autumn with individuals over $35.00 \mathrm{~mm}$, whereas for $C$. ornatus it started in spring with individuals over $30.00 \mathrm{~mm}$, which indicates that trawling fishery in Guanabara Bay is targeting juveniles of both species considering the size data at the first sexual maturation obtained in previous studies performed in Santa Catarina, São Paulo and Rio de Janeiro (Branco \& Thives 1991, Branco \& Lunardon-Branco 1993, Mantelatto \& Fransozo 1996, Keunecke, 2006).

The constant presence of $C$. danae and $C$.

\section{REFERENCES}

AMADOR, E. S. 1997. Baía de Guanabara e ecossistemas periféricos: homem e natureza. Rio de Janeiro: Elmo da Silva Amador, $539 \mathrm{p}$.

BRANCO, J.O. \& THIVES, A. 1991. Relação peso/largura, fator de condição e tamanho de primeira maturação de Callinectes danae Smith, 1869 (Crustacea, Portunidae) no Manguezal de Itacorubi, SC, Brasil. Arq. Biol. Tecnol., 34 (3/4): 415-424.

BRANCO, J.O.; LUNARDON, M.J.; LOYOLA E SILVA, J. DE \& ÁVILA, M.G. 1992a. Observações bioecológicas sobre o "siri-azul" Callinectes danae Smith, 1869 (Crustacea, Portunidae) da Baía Norte, Florianópolis, SC, Brasil. Arq. Biol. Tecnol., 35 (3): 557-564. BRANCO, J.O; LUNARDON, M.J.; AVILA, M.G. \& MIGUEZ, C.F. 1992b. Interação entre fator de condição e índice gonadossomático como indicadores do período de desova em Callinectes danae Smith (Crustacea, Portunidae) da Lagoa da Conceição, Florianópolis, Santa Catarina, Brasil. Rev. Bras. Zool., 9 (3/4): 175-180. ornatus in trawlings carried out at Guanabara Bay demonstrates that these species are important bycatch fauna components of the pink-shrimp fishery ( $F$. brasiliensis and $F$. paulensis). Actually, in the south and southeast regions of Brazil, the closed season of the pink-shrimp species are regulated by a governmental decree (IN 189, September 23th, 2008) that prohibits the capture of these species between March and May. This closed season aims to preserve the population of those species but ignores the bycatch fauna captured in that fishery. This fact may be extremely harmful for $C$. danae and $C$. ornatus populations inhabiting Guanabara Bay since ovigerous females and juveniles of both species were caught in the shrimp fishery.

Despite that $C$. danae and $C$. ornatus possess a great fishery potential in Guanabara Bay, their fisheries are not regulated. More studies are necessary on the fishery potential of these species in other regions of the country in order to regulate their fishery. The permanent maintenance of a collection system of fishery statistics is important as subsidy for policies of fomentation to fishery, organization of the fishery sector, and for quantification of eventual losses due to environmental accidents.

\section{ACKNOWLEDGEMENTS}

The first author wishes to thank Tereza Marques de Oliveira Lima, PhD, for revising the English manuscript. The authors wish to thank Francisco J. P. Matos for the availability of the biological material used in this work.

BRANCO, J.O. \& LUNARDON-BRANCO, M.L. 1993. Crescimento e tamanho de primeira maturação em Callinectes ornatus Ordway, 1863 (Decapoda, Portunidae) da região de Matinhos, Paraná, Brasil. Arq. Biol. Tecnol., 36 (3): 497-503.

BUCHANAN, B.A. \& STONER, A.W. 1988. Distributional patterns of blue crabs (Callinectes sp.) in a tropical estuarine lagoon. Estuaries, 4 (11): 231-239.

CARVALHO-CUNHA, P. 2003. Variação espaço-temporal dos decápodos capturados em arrastos de fundo, na Baía de Guanabara - RJ. Monografia de graduação, Universidade Federal do Rio de Janeiro (UFRJ). 71p.

CHACUR, M.M.; MANSUR, C.B. \& NEGREIROS-FRANSOZO, M.L. 2000. Distributional patterns, seasonal abundance and moult cycle of Callinectes danae Smith, 1869 in the Ubatuba region, Brazil. Nauplius, 8 (2): 215-226.

CHACUR, M.M. \& NEGREIROS-FRANSOZO, M.L. 2001. Spatial and seasonal distributions of Callinectes danae (Decapoda, Portunidae) in Ubatuba Bay, São Paulo, Brazil. J. Crust. Biol., 21 (2): 414-425. 
COSTA, T.M. \& NEGREIROS-FRANSOZO, M.L. 1998. The reproductive cycle of Callinectes danae Smith, 1869 (Decapoda, Portunidae) in the Ubatuba region, Brazil. Crustaceana, 71 (6): 615-627.

HAEFNER, P.A., JR. 1990. Morphometry and size at maturity of Callinectes ornatus (Brachyura, Portunidae) in Bermuda. Bull. Mar. Sci., 46 (2): 274-286.

JABLONSKI, S.; AZEVEDO, A.F. \& MOREIRA, L.H.A. 2006. Fisheries and conflicts in Guanabara Bay, Rio de Janeiro, Brazil. Braz. arch. biol. technol., 49 (1): 79-91.

KEUNECKE, K.A. 2006. Efeito da pesca de arrasto do camarãorosa sobre a dinâmica populacional de Callinectes danae e Callinectes ornatus (Crustacea, Portunidae) na Baía de Guanabara, Rio de Janeiro, Brasil. Tese de doutorado, Universidade Federal de São Carlos (UFSCar). 125p.

KEUNECKE, K.A.; D'INCAO, F.; MOREIRA, F.N.; SILVA JUNIOR, D.R. \& VERANI, J.R. 2008a. Idade e crescimento de Callinectes danae e C. ornatus na Baía de Guanabara, Rio de Janeiro, Brasil. Iheringia, Sér. Zool., 98(2): 231-235.

KEUNECKE, K.A.; SILVA JUNIOR, D.R.; VIANNA, M.; VERANI, J.R. \& D'INCAO, F. 2008b. Effects of migration activity on the mortality rates of two Portunidae crabs in a tropical bay. JMBA2 Biodiv. rcrds., published online.

KJERVE, B.; RIBEIRO, C.H.A.; DIAS, G.T.M.; FILIPPO, A.M. \& QUARESMA, V. S. 1997. Oceanographic characteristics of an impacted coastal bay: Baía de Guanabara, Rio de Janeiro, Brazil. Cont. Shelf Res., 17 (13): 1609-1643.

LAVRADO, H.P.; FALCÃO, A.P.C.; CARVALHO-CUNHA, P. \& SILVA, S.H.G. 2000. Composition and distribution of Decapoda from Guanabara Bay, RJ. Nauplius, 8 (1): 15-23.

MANTELATTO, F.L.M. \& FRANSOZO, A. 1992. Relação peso/largura da carapaça no caranguejo Hepatus pudibundus (Herbst, 1785) (Crustacea, Decapoda, Calappidae) na região de Ubatuba, SP, Brasil. Arq. Biol. Tecnol., 35 (4): 719-724.

MANTELATTO, F.L.M. \& FRANSOZO, A. 1996. Size at sexual maturity in Callinectes ornatus (Brachyura, Portunidae) from the Ubatuba region (SP), Brazil. Nauplius, 4: 29-38.

MANTELATTO, F.L.M. \& FRANSOZO, A. 1997. Fecundity of the crab Callinectes ornatus Ordway, 1863 (Decapoda, Brachyura, Portunidae) from the Ubatuba region, São Paulo, Brazil. Crustaceana, 70 (2): 214-226.

MANTELATTO, F.L.M. \& FRANSOZO, A. 1999. Reproductive biology and moulting cycle of the crab Callinectes ornatus (Decapoda, Portunidae) from the Ubatuba region, São Paulo, Brazil. Crustaceana, 72 (1): 63-76.
NEGREIROS-FRANSOZO, M.L. \& FRANSOZO, A. 1995. On the distribution of Callinectes ornatus Ordway, 1863 and Callinectes danae Smith, 1869 (Brachyura, Portunidae) in the Fortaleza Bay, Ubatuba, Brazil. Iheringia, Sér. Zool., 79: 13-25.

NEGREIROS-FRANSOZO, M.L.; MANTELATTO, F.L.M. \& FRANSOZO, A. 1999. Population biology of Callinectes ornatus Ordway, 1863 (Decapoda, Portunidae) from Ubatuba (SP), Brazil. Sci. Mar., 63 (2):157-163.

PINHEIRO, M.A.A. \& FRANSOZO, A. 1993. Análise da relação biométrica do peso úmido pela largura da carapaça para o siri Arenaeus cribarius (Lamarck, 1818) (Crustacea, Brachyura, Portunidae). Arq. Biol. Tecnol., 36 (2): 331-341.

PINHEIRO, M.A.A.; FRANSOZO, A. \& NEGREIROS-FRANSOZO, M.L. 1997. Dimensionamento e sobreposição de nichos dos portunídeos (Decapoda, Brachyura), na Enseada da Fortaleza, Ubatuba, São Paulo, Brasil. Rev. Bras. Zool., 14 (2): 371-378.

PITA, J.B.; SEVERINO-RODRIGUES, E.; GRAÇA-LOPES, R. \& COELHO, J.A.P. 1985. Levantamento da família Portunidae (Crustacea, Decapoda, Brachyura) no complexo baía-estuário de Santos, São Paulo, Brasil. B. Inst. Pesca 12 (3): 153-162.

REIGADA, A.L.D. \& NEGREIROS-FRANSOZO, M.L. 2001. Feeding activity of Callinectes ornatus Ordway, 1863 and Callinectes danae Smith, 1869 (Crustacea, Brachyura, Portunidae) in Ubatuba, SP, Brazil. Hydrobiologia, 449: 249-252.

SEVERINO-RODRIGUES, E.; PITA, J.B. \& GRAÇA-LOPES, R. DA. 2001. Pesca artesanal de siris (Crustacea, Decapoda, Portunidae) na região estuarina de Santos e São Vicente (SP), Brasil. B. Inst. Pesca, 27 (1): 7-19.

VILLAC, M.C.; MAYR, L.M.; TENENBAUM, D.R. \& PARANHOS, R. 1991. Sampling strategies proposed to monitoring Guanabara Bay (Brazil). In: Coastal Zone 91, 1991, San Diego. Proceedings of the 7th Symposium on Coastal and Ocean Management. New York: American Society of Civil Engineers. V 7. pp. 1168-1182.

WEBER, L.I.; PUCHNICK, A.; LAMEGO, J.P. \& LEVY, J.A. 2003. Genetic relationships among the most common swimming crabs of southern Brazil. J. Crust. Biol., 23 (1): 201-211.

WILLIAMS, A.B. 1974. The swimming crabs of the genus Callinectes (Decapoda: Portunidae). Fish. Bull., 72 (3): 685-798.

ZAR, J.H. 1986. Biostatistical Analysis. 3rd Ed. Prentice-Hall Inc., Upper Saddle River, New Jersey. 662p.

Recebido - 08/07/2008

Aceito: 01/06/2010 
